\title{
THE USE OF METFORMIN IN PATIENTS WITH POLYCYSTIC OVARY SYNDROME UNDERGOING IN VITRO FERTILIZATION
}

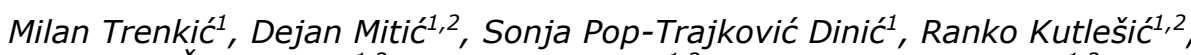

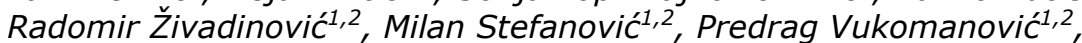 \\ Mirjana Krstić1, Aleksandra Aracki-Trenkić', Marija Trenkić-Božinović2,4
}

\begin{abstract}
Due to potential fertility benefits of metformin, it has become increasingly common for gynecologists to administer or continue metformin therapy in patients with polycystic ovary syndrome undergoing in vitro fertilization. We wanted to examine the effect of metformin in women with polycystic ovary syndrome undergoing in vitro fertilization. Metformin is used in patients with polycystic ovary syndrome, but the findings of its effects on the outcomes of in vitro fertilization have been conflicting. In the present study, which included 123 participants, we compared in vitro fertilization outcomes among women with polycystic ovary syndrome who were or were not given metformin. In patients treated with metformin, the length of stimulation was significantly longer. Further, we found a significantly greater thickness of the endometrium in the group of patients who had cotreatment with metformin. There was not any significant difference in the total dose of gonadotropins, median number of retrieved oocytes, and overall fertilization rates did not differ. Clinical pregnancy rates, missed abortions or multiple pregnancies were equal between the groups. A significant decrease in the incidence of ovarian hyperstimulation syndrome grade I was observed in the group of patients treated with metformin (group with metformin: $5.56 \%$ versus group without metformin: $17.39 \%$ ). While metformin does not improve the outcome of in vitro fertilization in patients with PCOS, its use in patients with PCOS undergoing in vitro fertilization significantly reduces the risk of OHSS Grade I. Acta Medica Medianae 2017;56(2): 18-24.
\end{abstract}

Key words: metformin, polycystic ovary syndrome, in vitro fertilization

\author{
Department of Gynecology and Obstretics, Clinical Center of \\ Niš, Serbia ${ }^{1}$ \\ University of Niš, Faculty of Medicine, Serbia ${ }^{2}$ \\ Center for Radiology, Clinical Center of Niš, Serbia ${ }^{3}$ \\ Department of Ophthalmology, Clinical Center of Niš, Serbia 4 \\ Contact: Milan Trenkić \\ Clinical Center of Niš \\ Zoran Đinđić Boulevard 48, 18000 Niš, Srbia \\ E-mail: trenkic@gmail.com
}

\section{Introduction}

Polycystic ovary syndrome (PCOS) is a common endocrine disorder primarily affecting women in their reproductive age. This syndrome can be diagnosed based on several different criteria. The most widely accepted are the Rotterdam criteria, which define PCOS as the presence of at least two out of the following three criteria: oligo-anovulation/anovulation, hyperandrogenism and polycystic ovaries, detected by ultra sound after the exclusion of other endocrine disorders (1). PCOS is usually associated with obesity, insulin resistance and compensatory hyperinsulinemia. Hyperinsulinemia contributes to anovulation, hyperandrogenism, infertility and early pregnancy loss in women with PCOS (2). Insulin resistance and hyperandrogenism play a key role in the pathophysiology of PCOS (3).

Insulin sensitizers such as metformin have been extensively investigated in the management of PCOS. Metformin decreases blood glucose levels by enhancing peripheral glucose uptake, decreasing intestinal glucose absorption and suppressing hepatic glucose levels. In anovulatory women with PCOS, metformin decreases insulin levels, luteinizing hormone (LH) production and circulating androgen levels (4).

Due to potential fertility benefits of metformin, it has become increasingly common for gynecologists to administer or continue metformin therapy in patients undergoing in vitro fertilization (IVF) (5). Numerous studies have evaluated the use of metformin in patients with PCOS undergoing IVF, and yet very weak conclusions can be drawn. When used for ovulation induction in PCOS patients, metformin has been found to 
increase ovulation and clinical pregnancy rates, although no clear evidence exist that metformin improves live birth rates whether it is used alone, in combination with clomiphene, or only clomiphene is used (6). In addition, the suppression of insulin levels in women with PCOS who are undergoing IVF or intracytoplasmic sperm injection (ICSI) may potentially improve the adverse effects of ovarian stimulation and produce better treatment outcomes $(7,8)$. A recent systematic review of met-formin co-administration before and during assisted reproductive technology (ART) among women with PCOS showed that the risk of ovarian hypersti- mulation syndrome (OHSS) was reduced with met-formin (9).

Studies to date have demonstrated variable results for metformin administration in PCOS patients undergoing IVF treatment with respect to reproductive outcomes. These studies had considerable heterogeneity in terms of patient characteristics, treatment protocols and study settings.

\section{Aims}

The aim of the present study was to investigate the effectiveness of metformin in improving reproductive outcomes in women with PCOS undergoing IVF.

\section{Patients and Methods}

This prospective study was conducted at the Department of Obstetrics and Gynecology, Clinical Center of Niš, Republic of Serbia, in 2013 and 2014 and was approved by the Ethics Committee. The study enrolled exclusively the patients with PCOS who fulfilled the Rotterdam criteria established by the recent ESHRE/ASRM Consensus (2004) i.e. those who, after the exclusion of other causes, met any two of the following three criteria: oligoovulation and/or anovulation, clinical or biochemical hyper- androgenism, and polycystic ovaries detected by ultrasound. The study enrolled 123 patients diagnosed with PCOS. The additional criteria for the inclusion were: $18-40$ years of age and body mass index (BMI) of $18-30 \mathrm{~kg} / \mathrm{m}^{2}$. The exclusion criteria were as follows: dysfunction of the thyroid or abnormal prolactin levels, abnormalities of the uterine cavity, ovarian cysts and surgically diagnosed endometriosis. The patients with PCOS were divided into two groups. One group was given metformin, whereas the other did not receive it. Metformin therapy started in the cycle before ovarian stimulation and was extended until clinical pregnancy was confirmed by ultrasound in the $7^{\text {th }}$ week of gestation.

In both groups, ovarian stimulation was performed by using either a standard long gonado tropin releasing hormone $(\mathrm{GnRH})$ agonist protocol or a flexible multidose $\mathrm{GnRH}$ antagonist protocol. The long protocol of $\mathrm{GnRH}$ agonist included a daily administered injection of $0.1 \mathrm{mg}$ triptorelin (Diphe reline, IpsenPharma Biotech, France), started in the mid-luteal phase of the previous menstrual cycle and continued until the administration of human chorionic gonadotropin (hCG). Estradiol and serum LH were measured 12 days later to confirm down-regulation and then gonadotropin stimulation was performed. The antagonist protocol consisting of daily gonadotropin stimulation was started on day 2 or 3 of menstruation. When the leading follicle reached the size of $14 \mathrm{~mm}$ and/or estradiol reached the value $>300 \mathrm{pg} / \mathrm{mL}$, a daily injection of $0.25 \mathrm{mg}$ cetrorelix (Cetrotide; MercSerono, Switzerland) was included. The treatment was continued until the day of hCG injection. Recombinant follicle stimulating hormone (FSH) (Gonal F, MercSerono, Switzerland) was used in both protocols for gonadotropin stimulation. The initial FSH dose was modified according to the ultrasound and hormonal assessment. A dose of 10.000 IU hCG (Pregnyl, Organon, Holland) was administered deeply i.m. when the leading follicle reached $\geq 18 \mathrm{~mm}$ in mean diameter, with the following two $\geq 16 \mathrm{~mm}$, or the three follicles reaching a mean diameter of $\geq 17 \mathrm{~mm}$. At 34-36 hours after hCG administration, transvaginal ultrasound-directed oocyte recovery was performed. Using a conventional IVF method, insemination was performed 38-40 hours after hCG administration. We performed embryo transfer under transabdominal ultrasound guidance. The embryos were transferred on Day 3. A daily dose of vaginal progesterone (Utrogestan $600 \mathrm{mg} /$ day; Laboratories Besins-International S.A., France) was used for the luteal phase support. Twelve days after the embryo transfer, a serum pregnancy test was used.

A modified classification system based on combined criteria reported by Golan et al. (10) was used to determine the grades of severity of OHSS. Patients having the symptoms of mild OHSS, such as abdominal distension and discomfort, were classified as Grade I. Other symptoms of mild OHSS included nausea, vomiting, diarrhea as well as an ovarian enlargement of $5-12 \mathrm{~cm}$. The features of mild OHSS in combination with the ascites detected by ultrasound were included in moderate OHSS or Grade II. The patients requiring hospitalization due to the development of a severe or critical OHSS or because their medical condition fulfilled one or more of the hospital admission criteria, were included in Grade III or severe OHSS. The hospital admission criteria required the presence of one of the following: ascites, hydrothorax, haematocrit $\geq 45 \%$, oliguria, elevated liver enzymes, dyspnoea, anasarca or acute renal failure.

\section{Statistical analysis}

The continuous variables were described by mean \pm standard deviations and by medians. For the categorical variables, absolute numbers and percentages were given. The distributions of the continuous variables were assessed for normality by Shapiro-Wilk test. The differences between independent groups were analyzed by an unpaired t-test in case of a normal distribution or by Mann-Whitney Test if a distribution of data was not normal. A chisquare test was used to compare the proportions of categorical variables between groups. The level of significance was set at 0.05 . The calculations were carried out using the SPSS statistical package version 15.0. 


\section{Results}

Out of 123 patients with polycystic ovary syndrome who were analysed in our study, 69 $(56.10 \%)$ patients used metaformin therapy, whereas 54 (43.90\%) patients received no therapy. There were no differences in age or hormone values between the patient groups. Body mass index was statistically higher in patients who used metformin. These parameters are shown in Table 1.

The results representing the characteristics of ovarian response to stimulation of ovulation in patients with PCOS, depending on whether or not they were treated with metformin, are shown in Table 2.

The total amount of gonadotropins (IU) used to stimulate ovulation in subjects treated with metformin (1691.12 \pm 517.10$)$ IU with a median of 1575.00 , is higher than in the group without metformin (1561.81 \pm 539.67$)$ with a median of 1562.50 , but not statistically significant. All other test para-meters that characterize ovarian response (number of follicles $\geq 16 \mathrm{~mm}$, number of oocytes aspirated, the number of mature and immature oocytes) were higher in the patients who used metformin, but without statistical significance. Statistically significantly higher values were the length of stimu-lation in the group of patients treated with met-formin $(10.80 \pm 2.18)$ compared to those not treated with it $(9.81 \pm 2.18)(p<0.05)$, and the thickness of endometrium $(p<0.01)$.

The success of in vitro fertilization in patients with PCOS, depending on the use of metformin is presented in Table 3 .

Table 1. Patient characteristics

\begin{tabular}{|l|c|c||c|c||}
\cline { 2 - 5 } \multicolumn{1}{c|}{} & \multicolumn{2}{c|}{$\begin{array}{c}\text { Group with metformin } \\
(\mathrm{n}=69)\end{array}$} & $\begin{array}{c}\text { Group without metformin } \\
(\mathrm{n}=54)\end{array}$ \\
\hline \hline Age $($ years $)$ & $31,57 \pm 4,42$ & $(32,00)$ & $31,72 \pm 3,56$ & $(32,00)$ \\
\hline BMI $\left(\mathrm{kg} / \mathrm{m}^{2}\right)$ & $23,75 \pm 2,91^{*}$ & $(24,00)$ & $22,73 \pm 2,89$ & $(22,00)$ \\
\hline FSH $(\mathrm{mIU} / \mathrm{ml})$ & $5,44 \pm 1,66$ & $(5,20)$ & $5,41 \pm 1,83$ & $(5,10)$ \\
\hline LH $(\mathrm{mIU} / \mathrm{ml})$ & $7,00 \pm 3,00$ & $(6,60)$ & $7,19 \pm 2,69$ & $(7,10)$ \\
\hline AMH $(\mathrm{ng} / \mathrm{ml})$ & $6,72 \pm 3,37$ & $(6,70)$ & $7,06 \pm 3,28$ & $(6,05)$ \\
\hline LH/FSH & $1,36 \pm 0,61$ & $(1,17)$ & $1,54 \pm 0,96$ & $(1,37)$ \\
\hline
\end{tabular}

Table 2. Results of ovarian stimulation in patients with PCOS treated with or without metformin.

\begin{tabular}{|l|c|c||c|c||}
\cline { 2 - 5 } \multicolumn{1}{c|}{} & \multicolumn{2}{c|}{$\begin{array}{c}\text { Group with metformin } \\
(n=69)\end{array}$} & \multicolumn{2}{c||}{\begin{tabular}{c} 
Group without metformin \\
\multicolumn{1}{c|}{$(n=54)$}
\end{tabular}} \\
\hline Days of stimulation & $10,80 \pm 2,18^{*}$ & $(11,00)$ & $9,81 \pm 2,18$ & $(9,00)$ \\
\hline Total dose of gonadotropins (IU) & $1691,12 \pm 517,10$ & $(1575,00)$ & $1561,81 \pm 539,67$ & $(1562,50)$ \\
\hline Number of follicles $\geq 16 \mathrm{~mm}$ & $13,14 \pm 6,17$ & $(13,00)$ & $12,15 \pm 7,04$ & $(12,00)$ \\
\hline Number of oocytes obtained & $14,06 \pm 7,89$ & $(13,00)$ & $12,78 \pm 7,38$ & $(10,50)$ \\
\hline Number of mature oocytes & $10,00 \pm 6,20$ & $(9,00)$ & $8,85 \pm 5,99$ & $(7,00)$ \\
\hline Number of immature oocytes & $4,26 \pm 3,25$ & $(4,00)$ & $3,93 \pm 3,63$ & $(3,00)$ \\
\hline Endometrial thickness (mm) & $10,58 \pm 1,44^{* *}$ & $(10,50)$ & $9,90 \pm 1,47$ & $(9,50)$ \\
\hline
\end{tabular}

The incidence of clinical pregnancies per ET was higher (33, i.e. $49.25 \%$ ) in the group of patients with PCOS who were treated with metformin, compared to the subjects who did not use metformin (24, i.e. $48.00 \%)$; the occurrence of biochemical pregnancis was also higher in these (2, i.e. $2.99 \%)$, compared to the subjects who did not use metformin (1, i.e. $2.00 \%$ ). As a consequence of the above, the total number of pregnancies (clinical and biochemical) was higher in the group of patients who used metformin, but not statistically significantly higher (35, i.e. $52.24 \%$ compared to 25 , i.e. $50.00 \%$ ). In the same group, the rate of implantation was higher $(24.16 \%$ vs. $20.71 \%)$, but with no statistically significant differences compared to the group of subjects who did not use metformin. In the group treated with metformin, multifetal pregnancy rate was higher $(25.71 \%$ vs. $16.00 \%)$, but again without statistically significant differences. The case was the same with the abortion rate $(15.15 \%$ vs. $12.50 \%)$. The number of cancelled cycles in relation to the total number of subjects was higher 
in the group which did not receive metformin therapy (4, i.e. $7.41 \%)$ than in the group which used metformin (1, i.e. $2.90 \%)$. Representation of OHSS grade I (12, i.e. $17.39 \%)$ was significantly higher in the study group without metformin than in the group with metformin (3, i.e. $5.56 \%$ ) $-p<0.05$.

\section{Discussion}

Insulin resistance is identified as one of the key factors contributing to the pathophysiology of

Table 3. IVF outcome parameters in patients with or without metformin.

\begin{tabular}{|l|c||c||}
\cline { 2 - 3 } \multicolumn{1}{c|}{} & $\begin{array}{c}\text { Group with metformin } \\
(\mathrm{n}=69)\end{array}$ & $\begin{array}{c}\text { Group without metformin } \\
(\mathrm{n}=54)\end{array}$ \\
\hline Implantation rate & $24,16 \%$ & $: 20,71 \%$ \\
\hline Fertilization rate & $66,39 \%$ & $: 65.80 \%$ \\
\hline Total No. of pregnancies per ET(\%) & $35: 52,24 \%$ & $25: 50,00 \%$ \\
\hline Clinical pregnancies per ET(\%) & $33: 49,25 \%$ & $24: 48,00 \%$ \\
\hline Biochemical pregnancies per ET(\%) & $2: 2,99 \%$ & $1: 2,00 \%$ \\
\hline Multiple pregnancy rate & $: 25,71 \%$ & $: 16,00 \%$ \\
\hline Miscarriage rate & $: 15,15 \%$ & $: 12,50 \%$ \\
\hline Cancelled cycles & $2: 2,90 \%$ & $4: 7,41 \%$ \\
\hline OHSS & $4: 7,41 \%$ & $13: 18,84 \%$ \\
\hline OHSS grade I & $3: 5,56 \%$ & $12: 17,39 \%$ \\
\hline OHSS grade II & $1: 1,85 \%$ & $1: 1,45 \%$ \\
\hline
\end{tabular}

the disease in patients with polycystic ovary syndrome. Having in mind the role of insulin resistance in PCOS, insulin sensitizers have drawn much attention in considering the treatment options for infertility in this population. Metformin, a biguanide oral antihyperglycemic, has been often investigated over the last 20 years. Because of its potential benefits on fertility, metformin therapy is commonly prescribed by gynecologists, or continued as the treatment for patients undergoing in vitro fertilization. So far, studies have produced controversial results of the use of metformin in PCOS patients undergoing IVF treatment in relation to the reproductive outcome. The most common indications for the use of metformin in IVF cycles are high levels of serum insulin, PCOS associated with obesity and anovulation, glucose intolerance, insulin resistance, or PCOS displaying clinical or biochemical signs of hyperandrogenism, patients with PCOS who have had abortions and PCOS patients who had poorquality oocytes retrieved in the previous cycle.

Tang et al. (2006) conducted one of the first major studies examining the effect of metformin on IVF treatment in PCOS patients (8). It was a randomized, placebo-controlled double-blind study which included 101 IVF cycles. The authors found no difference in the dose of gonadotropins, number of retrieved oocytes, fertilization rate and embryo quality. However, in the group using metformin there was a statistically significant higher rate of clinical pregnancies per cycle $(38.5 \%$ compared to $16.3 \%, p=0.02$ ) and of clinical pregnancies after embryo transfer (44.4\% compared to $19.1 \%, p=0.02$ ). Similarly, ovarian hypersti- mulation syndrome occurred with a lower incidence $(3.8 \%)$ in the metformin group, as compared to $20.4 \%$ in the placebo group $(p=0.02)$. The conclusion of this study was that although a brief co-treatment with metformin in PCOS patients undergoing IVF/ICSI cycles did not improve the response to stimulation, it significantly increased pregnancy rate and reduced the risk of OHSS. A study done by Kjotrod et al. (2011) examined the effect of metformin in 150 non-obese women with PCOS (BMI $<28 \mathrm{~kg} / \mathrm{m}^{2}$ ) undergoing IVF (11). The subjects were treated with metformin for at least 12 weeks before the IVF cycle. Among IVF-treated women, there was no difference in clinical pregnancies between the metformin and placebo groups. However, due to the spontaneous conceptions that occurred prior to IVF, there was a significantly higher incidence of clinical pregnancies (50.0\% compared to $33.3 \%, p=0.04$ ) and live births (48.6\% compared to $32.0 \%, p=0.04$ ) in the group with metformin. Palomba et al. (2013) performed a systematic review and meta-analysis of ten randomized controlled trials examining the use of metformin in the IVF treatment of PCOS patients (12). The meta-analysis included 845 patients. This study found that the use of metformin had no effect on the rate of clinical pregnancies (OR 1.2, 95\% CI $0.90-1.61$ ) or the rate of live births (OR $1.7,95 \%$ CI 0.85-3.34). The authors published the finding that metformin was associated with a reduced risk of OHSS (OR $0.27,95 \%$ CI 0.16 to 0.46 ) and a reduced risk of miscarriage (OR $0.50,95 \%$ CI 0.3-0.83).

We found no difference in the ovarian response in patients treated with metformin during IVF 
therapy, compared to those without metformin therapy. The quantities of gonadotropin used for the treatment did not differ between the groups. The number of aspirated oocytes, the number of mature oocytes and fertilization rates were comparable. The duration of stimulation differed because it lasted longer in patients who used metformin stimulation, compared to those who did not take metformin. Similarly, the patients on metformin therapy had statistically significantly thicker endometrium. Our opinion was that those differences could not influence the outcome. The rates of clinical pregnancies per embryo transfer and abortion rates also did not differ. There were no differences with regard to multifetal pregnancies either. We demonstrated a statistically significant difference of OHSS grade I in the group of patients without metformin $(p<0.05)$. Our results are largely consistent with the results of the meta-analysis done by Palomba and associates (12).

Various findings of individual studies and meta-analyses indicate that the effect of metformin on the outcome of IVF treatment in PCOS patients is a variable largely dependent upon the clinical phenotype of the patient. Significant variability exists with regard to protocols of metformin application during the IVF procedure. Starting the administration of metformin is related to a period of at least 3 months prior to IVF or usually just before the start of stimulation. The time of treatment cessation also differed; some authors interrupted the use of metformin on the day of the positive pregnancy test or at 12 weeks' gestation. This variability trend was also reflected in the drug dose administered, which ranged from $1000-2500 \mathrm{mg} /$ day, usually between 1500 and $2000 \mathrm{mg} /$ day.

Teissier et al. (2000) suggested that the micro-follicular endocrine environment was responsible for the quality of oocytes in women under-going IVF and that the excess concentration of follicular androgens could affect the quality of oocytes (13). Tang et al. (8) showed that 4 weeks of cotreatment with metformin reduced serum levels of testosterone and free androgen (FAI). However, in order for the quality of oocytes to improve, metformin treatment should begin at least three months before the IVF cycle, which is the period of time needed for the maturation of the primordial into antral follicles (14).

Many authors have tried to prove the pos- tulate that the use of metformin improves pregnancy outcomes, and also to explain the mechanism behind it. It is known that androgen levelsin the blood increase during ovarian stimulation in IVF cycles, and that these levels tend to be higher in PCOS patients. High levels of androgens are also known to negatively affect the outcome of pregnancy $(15,16)$.

In his study, Tang demonstrated that the levels of total testosterone and FAI were significantly lower in the metformin group. He also demon strated that metformin reduces the level of estradiol on the day of administration of hCG. In addition, insulin and insulin like growth factor I (IGFI) increased the stimulatory effect of FSH on estrogen production in the granulosa cells. Therefore, the effects of metformin on reducing androgens and insulin could also contribute to the reduction of the concentration of estradiol. Furthermore, the rapid biochemical improvement in serum testosterone and estradiol after only a short administration of metformin may be explained by all these findings.

It is a long-known fact that patients with PCOS undergoing IVF treatment have an increased risk of developing OHSS. The pathogenesis of OHSS is characterized primarily by increased capillary permeability and increased vascular endothelial growth factor (VEGF) levels. VEGF is an endothelial cell mitogen with strong angiogenic properties and it is considered to be a key mediator of OHSS. Higher serum VEGF levels were found in patients with PCOS on the day of oocyte aspiration, compared to the control group and also in women developing OHSS (17). In addition, Miele et al. (2000) showed that insulin and IGF-I increase expression of VEGF mRNA (18). Based on the above evidence, the reduced incidence of OHSS in PCOS patients who used metformin can be attributed to its effect of reducing the insulin levels and consequently reducing the production of VEGF (19).

\section{Conclusions}

While metformin does not improve the outcome of in vitro fertilization in patients with PCOS, its use in patients with PCOS undergoing in vitro fertilization significantly reduces the risk of OHSS Grade I. 


\section{References}

1. Rotterdam ESHRE/ASRM-Sponsored PCOS Consensus Workshop Group. Revised 2003 conse-nsus on diagnostic criteria and long-term health risks related to polycystic ovary synd rome (PCOS). Hum Reprod 2004;19(1):41-7. [PubMed] [CrossRef]

2. Al-Biate MA. Effect of metformin on early pregna-ncy loss in women with polycystic ovary syndro-me. Taiwan J Obstet Gyne 2015; 54(3):266-9. [PubMed] [CrossRef]

3. Stepto NK, Cassar S, Joham AE, Hutchison SK, Harrison CL, Goldstein RF, et al. Women with polycystic ovary syndrome have intrinsic insulin resistance on euglycaemic-hyperinsulaemic clamp. Hum Reprod 2013;28(3):777-84. [PubMed] [CrossRef]

4. Barbieri RL. Metformin for the treatment of polycystic ovary syndrome. Obstet Gynecol 2003;101(4):785-93. [PubMed] [CrossRef]

5. Thessaloniki ESHRE/ASRM-Sponsored PCOS Consensus Workshop Group. Consensus on infertility treatment related to polycystic ovary syndrome. Hum Reprod 2008; 23(3): 462-77. [PubMed] [CrossRef]

6. Tang T, Lord JM, Norman RJ, Yasmin E, Balen AH. Insulin-sensitising drugs (metformin, rosiglitazone, pioglitazone, D-chiroinositol) for women with polycystic ovary syndrome, oligo amenorrhoea and subfertility. Cochrane DB Syst Rev 2010; 20(1):CD003053. [PubMed] [CrossRef]

7. Kjotrod SB, von During V, Carlsen SM. Metfor-min treatment before IVF/ICSI in women with polycystic ovary syndrome; a prospective, randomized, double blind study. Hum Reprod 2004;19(6):1315-22. [PubMed] [CrossRef]

8. Tang $\mathrm{T}$, Glanville J, Orsi N, Barth JH, Balen AH. The use of metformin for women with PCOS undergoing IVF treatment. Hum Reprod 2006; 21(6):1416-25. [PubMed] [CrossRef]

9. Tso LO, Costello MF, Albuquerque LE, Andriolo RB, Freitas V. Metformin treatment before and during IVF or ICSI in women with polycystic ovary syndrome. Cochrane DB Syst Rev 2009; 15(2):CD006105. [PubMed] [CrossRef]

10. Golan A, Ron-el R, Herman A, Soffer Y, Weinraub $Z$, Caspi E. Ovarian hyperstimulation syndrome: an update review. Obstet Gynecol Surv 1989;44(6):430-40. [PubMed] [CrossRef]

11. Kjotrod SB, Carlsen SM, Rasmussen PE, HolstLarsen T, Mellembakken J, Thurin-Kjellberg A, et al. Use of metformin before and during assisted reproductive technology in non-obese young infertile women with polycystic ovary syndrome: a prospective, randomized, double-blind, multicentre study. Hum Reprod 2011; 26(8):2045-53. [PubMed] [CrossRef]

12. Palomba S, Falbo A, La Sala GB. Effects of metformin in women with polycystic ovary syn-drome treated with gonadotrophins for in vitro fertilisation and intracytoplasmic sperm injection cycles: a systematic review and meta-analysis of randomised controlled trials. BJOG-Int J Obstet Gy 2013; 120(3):267-76. [PubMed] [CrossRef]

13. Teissier MP, Chable $\mathrm{H}$, Paulhac $\mathrm{S}$, Aubard $\mathrm{Y}$. Comparison of follicle steroidogenesis from normal and polycystic ovaries in women undergoing IVF: relationship between steroid concentrations, follicle size, oocyte quality and fecundability. Hum Reprod 2000;15(12):2471-7. [PubMed] [CrossRef]

14. Gougeon A. Regulation of ovarian follicular development in primates: facts and hypo theses. Endocr Rev 1996; 17(2):121-55. [PubMed] [CrossRef]

15. Kodama H, Fukuda J, Karube H, Matsui T, Shimizu $Y$, Tanaka T. High incidence of embryo transfer cancellations in patients with polycystic ovarian syndrome. Hum Reprod 1995; 10(8): 1962-7. [PubMed] [CrossRef]

16. Fanchin $R$, de Ziegler $D$, Taieb J, Olivennes $F$, Castracane VD, Frydman R. Human chorionic gonadotropin administration does not increase plasma androgen levels in patients undergoing controlled ovarian hyperstimulation. Fertil Steril 2000;73(2):275-9. [PubMed] [CrossRef]

17. Wang TH, Horng SG, Chang CL, Wu HM, Tsai YJ, Wang HS, et al. Human chorionic gonado tropininduced ovarian hyperstimulation syn drome is associated with up-regulation of vascular endo-thelial growth factor. J Clin Endocr Metab 2002;87(7):33008. [PubMed] [CrossRef]

18. Miele C, Rochford JJ, Filippa N, Giorgetti-Peraldi S, Van Obberghen $\mathrm{E}$. Insulin and insulin-like growth factor-I induce vascular endothelial growth factor mRNA expression via different signaling pathways. J Biol Chem 2000;275(28):21695-702. [PubMed] [CrossRef]

19. Fleming R, Harborne L, MacLaughlin DT, Ling D, Norman J, Sattar N, et al. Metformin reduces serum mullerian-inhibiting substance levels in women with polycystic ovary syndrome after protracted treatment. Fertil Steril 2005;83(1):

130-6. [PubMed] [CrossRef] 


\title{
UPOTREBA METFORMINA KOD BOLESNICA SA SINDROMOM POLICISTIČNIH JAJNIKA PODVRGNUTIH VANTELESNOM OPLOĐENJU
}

\author{
Milan Trenkić ${ }^{1}$, Dejan Mitić ${ }^{1,2}$, Sonja Pop-Trajković Dinić ${ }^{1}$, Ranko \\ Kutlešić $^{1,2}$, Radomir Živadinović ${ }^{1,2}$, Milan Stefanović ${ }^{1,2}$, Predrag \\ Vukomanović ${ }^{1,2}$, Mirjana Krstić ${ }^{1}$, Aleksandra Aracki-Trenkić ${ }^{3}$, Marija \\ Trenkić-Božinović ${ }^{2,4}$
}

\author{
Klinika za ginekologiju i akušerstvo, Klinički centar Niš, Srbija ${ }^{1}$ \\ Univerzitet u Nišu, Medicinski fakultet, Niš, Srbija² \\ Centar za radiologiju, Klinički centar Niš, Srbija ${ }^{3}$ \\ Klinika za očne bolesti, Klinički centar Niš, Srbija ${ }^{4}$ \\ Kontakt: Milan Trenkić \\ Klinika za ginekologiju i akušerstvo, Klinički centar Niš \\ Bulevar Zorana Đinđića 48, 18000 Niš, Srbija \\ E-mail: trenkic@gmail.com
}

Zbog potencijalne koristi metformina po plodnost, postala je uobičajena praksa da ginekolozi uključuju ili produžavaju već ordiniranu terapiju metforminom kod bolesnica sa sindromom policističnih jajnika koje su u postupku vantelesnog oplođenja. Želeli smo da istražimo efekat metformina kod žena sa sindromom policističnih jajnika u postupku vantelesnog oplođenja. Metformin se koristi kod bolesnica sa sindromom policističnih jajnika, ali nalazi za njegov uticaj na ishod vantelesnog oplođenja su oprečni.

U ovoj studiji, koja obuhvata 123 bolesnice, poredili smo ishod vantelesnog oplođenja između žena sa sindromom policističnih jajnika koje su koristile i onih koje nisu koristile metformin. Kod bolesnica tretiranih metforminom, dužina stimulacije bila je signifikantno duža. Takođe, našli smo i signifikantno veću debljinu endometrijuma kod bolesnica koje su imale ko-tretman metforminom. Nije bilo signifikantne razlike u ukupnoj dozi gonadotropina, srednjem broju dobijenih oocita i stopi fertilizacije koja se nije razlikovala. Stope kliničkih trudnoća, pobačaja i multifetalnih trudnoća bile su slične u obe grupe. Značajno manja incidencija ovarijalnog hiperstimulacionog sindroma gradusa I primećena je u grupi bolesnica tretiranih metforminom (grupa sa metforminom: 5,56\% prema grupi bez metformina: $17,39 \%$ ). Metformin ne poboljšava ishod vantelesnog oplođenja kod bolesnica sa PCOS-om. Tretman metforminom kod bolesnica sa sindromom policističnih jajnika podvrgnutim vantelesnom oplođenju značajno smanjuje rizik za nastanak ovarijalnog hiperstimulacionog sindroma gradusa I. Acta Medica Medianae 2017;56(2):18-24.

Ključne reči: metformin, sindrom policističnih jajnika, vantelesno oplođenje 